Relations industrielles

Industrial Relations

\title{
Storey, John, ed., Human Resource Management: A Critical
}

\section{Text}

\section{Michael Poole}

Volume 51, numéro 2, 1996

Nouveaux modèles de négociation, de résolution de conflits et de solutions conjointes de problèmes

New Models of Negotiations, Dispute Resolution and Joint Problem

Solving

URI : https://id.erudit.org/iderudit/051103ar

DOI : https://doi.org/10.7202/051103ar

Aller au sommaire du numéro

Éditeur(s)

Département des relations industrielles de l'Université Laval

ISSN

0034-379X (imprimé)

1703-8138 (numérique)

Découvrir la revue

Citer ce compte rendu

Poole, M. (1996). Compte rendu de [Storey, John, ed., Human Resource

Management: A Critical Text]. Relations industrielles / Industrial Relations, 51(2),

419-420. https://doi.org/10.7202/051103ar

Tous droits réservés @ Département des relations industrielles de l'Université Laval, 1996
Ce document est protégé par la loi sur le droit d'auteur. L'utilisation des services d'Érudit (y compris la reproduction) est assujettie à sa politique d'utilisation que vous pouvez consulter en ligne.

https://apropos.erudit.org/fr/usagers/politique-dutilisation/ 


\section{Human Resource Management: A Critical Text}

edited by John STOREY, London and New York, Routledge, 1995, 399 p., ISBN 0-415-09149-7 (hbk) and ISBN 0-415-09150-0 (pbk).

The current volume comprises a series of critical readings on human resource management which, arguably, has had a greater impact on the academic industrial relations community than any other single development in recent years. The contributors are largely British and include many leading figures in the field.

The book itself is divided into four main parts (1) an introduction, (2) strategic issues, (3) key practice areas of human resource management and (4) international human resource management. In the compass of a single review it is not appropriate to evaluate every contribution in depth. What follows therefore is an examination of a limited number of chapters after detailing the contributions in each area.

In the introduction, there are two main chapters by John Storey and Karen Legge respectively. Both are good reviews but what emerges from John Storey's chapter in particular is the recognition of the very limited amount of systematic empirical work to make some sense of the leading changes (assuming major changes have in fact taken place). To make progress in the years ahead it is clearly at an empirical level that the main advances are required and these should be encouraged in the form of surveys and case studies.

On strategic issues, all the chapters (by John Purcell, Keith Sisson, David Guest and Peter Armstrong) are valuable. What stems from the last mentioned contribution is the importance of accountancy and financial management for human resource management. As Peter Armstrong himself points out (p. 157-158):

The post-1970s decline in collective bargaining in Great Britain has precipitated a great deal of academic/prescriptive speculation on the future of the personnel profession. Missing from much of this work is an awareness of the overall context of corporate control within which that future will be worked out. An exception is Legge's (1978) discussion of 'conformist' and 'deviant' innovation, in which the relationship of personnel initiatives to their context is implicit. Since a core feature of the modern British corporation is its permeation with the characteristic performance targets, information flows and culture of management accounting, it is this which most importantly defines what is conformist and what is deviant.

The important inference of the far reaching impact on human resource management of financial constraints (and the language and discourse of financial management) is an obvious but highly consequential one.

In respect of key practice areas, there are contributions by Sheila Rothwell (human resource planning); Paul lles and Graeme Salaman (recruitment, selection and assessment); David Ashton and Alan Felstead (training and development); Ian Kessler (reward systems) and Mick Marchington (involvement and participation). Mick Marchington's chapter confirms that some types of employee involvement undoubtedly advanced in the 1980 's even though the reality is somewhat more 'mundane' and arguably 'faddist'. Above all line managers have not really had the enthusiasm and commitment to make EI institutions work in practice. Collective bargaining, in the U.K. at least, had declined and the works councils initiative is an item of recent political interest (even if they are neither new nor widespread in British companies).

The final part of the text is arguably the most interesting of all and develops 
an international human resource management perspective. The chapters involve Chris Brewster (Europe), Thomas Kochan and Lee Dyer (America) and Hugh Scullion (international human resource management); coupled with a final future prospects chapter by John Storey. In this respect, the work by Chris Brewster in developing a European model of human resource management and in his role in the Price Waterhouse/Cranfield researches is worth a special mention. After all, at both theoretical and empirical levels this has added a rich new dimension to earlier analyses and debates.
In sum, this is an important text. It comprises contributions from many leading U.K. scholars in the field. It has an added international dimension and the chapters are informative and well written. If the empirical work on human resource management ultimately matches the quality of current critical contributions we will achieve the desirable goal of critically informed empirical analyses of the area and the transcendance of earlier prescriptive approaches linked with personnel management itself.

MICHAEL, POOLE Cardiff Business School, U.K.

\section{Catching the Wave: Workplace Reform in Australia}

by John MATHEWS, Ithaca, N.Y., ILR Press, 1994, 359 p., ISBN 0-87546-707-5

(cloth), and ISBN 0-87546-706-7 (pbk).

In his field John Mathews is a well known, prolific Australian writer. His works have taken a broad sweep from left political pamphleteering through occupational health and safety, technological change and industrial restructuring. Since the mid 1980s Mathews has turned his attention to workplace change and along with much of the Australian 'Ieft' has increasingly reflected managerial concerns in this pursuit. Mathews was an influential advocate of the strategic document known as the Accord, an agreement between Australia's peak union body, the Australian Council of Trade Unions and the Australian Labor Party, by which Australian unions were to gain influence over public policy in exchange for wage restraint and cooperation with industrial rationalization. Although later to lead the union movement into a direction of industrial relations decentralization and labour market flexibility informed essentially by business interests this strategy was for Mathews in the vernacular of the day, a 'powerful engine of socialist advance'. From the mid 1980s the unions' original objectives altered. The recasting of Australian public policy was forgotten, and (along with Australia's business interests) the unions co-operated with the Hawke/Keating Labor Government in workplace change and labour market 'flexibility' to improve international competitiveness. Mathews was an intellectual leader of this shift through his advocacy of 'post-Fordism' according to which the moving forces of history embodied in the grand shift from 'Fordism' to 'post-Fordism' made work reorganization and 'industrial democracy' necessary for economic survival.

These ideas were subjected to considerable criticism and Mathews has in Catching the Wave apparently jettisoned the Fordist/post-Fordist divide which he finds no longer 'helpful' (p. 309). While he has deemphasized his former theoretical predilection many of the key ideas remain, in particular the image of a wave of change washing over the world of work as a result of the "end of mass production'. Other ideas have been recast to reflect trends in the current debate. At times this imposes stresses on the book's logical consistency. Formerly an advocate of 'post-Fordist' work organisation, above all exemplified in 'lean production', Mathews now identifies 'two competing paradigms of industrial efficiency' of which one is lean production and the other is what he calls the 'sociotechnical 